Autora: Prof. Dra. Carolina Torres Oliveira

Instituição: Instituto Federal de Brasília

E-mail: carolina.oliveira@ifb.edu.br ou carol.profa@gmail.com

Área Temática: Teoria da subjetividade: discussões conceituais e relações com outros referenciais teóricos

\title{
O SOCIAL E A SUBJETIVIDADE DO ESPAÇO ESCOLAR A PARTIR DA TEORIA HISTÓRICO-CULTURAL
}

RESUMO: O texto orientador deste escopo propõe pensar o social e a subjetividade ancorando estudos dentro da Teoria Histórico-Cultural, que tem as produções de Lev Semenovich Vigotsky em seus fundamentos teóricos. São destacadas concepções e explanados momentos de reflexões de processos educativos com base em obras desse teórico e de alguns dos que se apropriaram de sua abordagem, gerando profícuas contribuições - a exemplo de Leontiev -, além de evidenciar a Teoria da Subjetividade elaborada pelo psicólogo cubano González Rey, ancorada nessa abordagem como um de seus fundamentos. Vigotsky (1984), Leontiev (1983) e Luria (1985) explicaram o psiquismo humano estudando as funções psíquicas superiores, como atenção, memória, pensamento, linguagem, consciência, dentre outras, tendo como princípio orientador a raiz social dos processos psíquicos. Eles defenderam que o psiquismo tem uma gênese social, desenvolve-se e transforma-se no decorrer da história da sociedade humana conforme as relações sociais, históricas e culturais que delas derivaram. O advento dessa psicologia trouxe um novo entendimento da constituição do ser, no qual o social passa a ser valorizado. Dentre os desdobramentos desses pressupostos para a compreensão da especificidade do psicológico e seus processos de constituição, está a subjetividade. Vigotsky não discute a subjetividade em suas obras, entretanto outros autores propuseram-se a discuti-la tendo em vista os estudos vigotskyanos. Mesmo não sendo um desdobramento direto, nesta abordagem está a Teoria da Subjetividade desenvolvida por González Rey (1997, 2012). Dentro das dinâmicas conceituais deste referencial teórico existe um conjunto de categorias como sentido subjetivo, subjetividade social, subjetividade individual e configurações subjetivas que se tornam importantes vias de explicações e geradoras de construções. Garantem representações mais complexas e abrangentes da subjetividade. Uma compreensão aprimorada de aspectos como o social e a subjetividade no espectro da Teoria Histórico-Cultural pode contribuir para o desenvolvimento epistemológico de processos educativos, além da construção de um espaço 
escolar de constituição cultural de indivíduos que se expressem como sujeitos nos termos da Teoria da Subjetividade de González Rey. Portanto, no trabalho científico arquitetado, são tecidos fundamentos da Teoria Histórico-Cultural, dando enfoque ao social; articulações desses fundamentos com a Teoria da Subjetividade e algumas ressonâncias na educação escolar. Neste recorte textual, uma questão a ser discutida e vinculada a essa temática pode ser assim apresentada: "Como o social se expressa na subjetividade do espaço escolar?"

PALAVRAS-CHAVE: Social; Teoria da Subjetividade; Teoria Histórico-Cultural.

\section{REFERÊNCIAS:}

LEONTIEV, A. N. Actividad, conciencia, personalidad. La Habana: Editorial Pueblo y Educación, 1983.

LURIA, A. R. Linguagem e desenvolvimento intelectual na criança. Porto Alegre: Artes Médicas, 1985.

VIGOTSKY, L. S. A formação social da mente. São Paulo: Martins Fontes, 1984.

GONZÁLEZ REY, F. L. La subjetividad social y su expresión en la enseñanza. Temas psicol., Ribeirão Preto, v.5, n.3, p.95-107, dez. 1997.

O social na psicologia e a psicologia no social: a emergência do sujeito. 3. ed. Petrópolis, RJ: Vozes, 2012. 